\title{
INTEGRATED REPORTING: A STORY OF STAKEHOLDER ACCOUNTABILITY
}

\author{
Chisinga N. Chikutuma \\ University of South Africa
}

\begin{abstract}
The paper reflects on how different reporting frameworks developed over time as accountability adapted to changing needs of stakeholders which arguably contributed to the development of Integrated Reporting. A conceptual approach and a structured literature review are the methods employed in the paper. The paper dismisses the notion held in the literature that Integrated Reporting only began in 2010 (de Villiers, Rinaldi and Unerman, 2014) with the establishment of the Integrated Reporting Council (IIRC). Furthermore, the ever changing needs of stakeholders contributed to the growth of different reporting systems (Financial Reporting, Balanced Scorecard, Triple Bottom Line, Sustainability Reporting and Integrated Reporting). The paper may provide regulators, reporting organisations and academics with an accountability context in which the evolution of Integrated Reporting occurred. The paper departs from the popular view that <IR> began in 2010 and offers insights of how the changing dynamics of accountability due to the continuous change in stakeholders' needs contributed to the birth and development of $\langle\mathrm{IR}\rangle$. The paper further challenges $<\mathrm{IR}>$ that while it may successfully overcome some of the limitations of Financial Reporting, Balanced Scorecard, Triple Bottom Line, Sustainability Reporting; it still has a long way to go in order to address its own shortcomings.
\end{abstract}

Keywords: Balanced Scorecard, Triple Bottom Line, Sustainability Reporting, Integrated Reporting

\section{JEL code: M41}

\section{Introduction}

Integrated Reporting $(<\mathrm{IR}\rangle)$ is defined as "a process founded on integrated thinking that results in a periodic integrated report by an organization about value creation over time and related communications regarding aspects of value creation" (International Integrated Reporting Council [IIRC], 2013). In other words, $<$ IR $>$ pertains to how an entity will thrive in the short, medium and long-term not only focussing on the financial profit, but rather on the environment and all stakeholders at large (Adams, 2013). 〈IR $\rangle$ is primarily aimed at providers of capital, but is of interest to various stakeholders (Adams, 2013). It should be noted that the focus of $\langle\mathrm{IR}>$ is on meeting the needs of not only shareholders but also those of stakeholders by clearly articulating how value will be created and sustained in future for the entity itself and the society by making use of the different capitals. The $\langle\mathrm{IR}>$ framework identifies three fundamental concepts which are identified as value-creation for the organisation and for others, the capitals and the value creation process (Flower, 2015). The entity uses the six capitals as inputs in its business model and through business activities; capitals may increase, decrease or get transformed. Through business activities, entities preparing integrated reports are guided by seven guiding principles namely strategic focus, connectivity of information, materiality, conciseness, reliability and completeness, and consistency and comparability (IIRC, 2013). Furthermore, the $\langle$ IR $\rangle$ framework proclaims the content elements which must guide preparation of integrated reports and are identified as organisational overview and the external environment, governance, business model, risks and 
opportunities, strategy and resource allocation, performance outlook, basis of preparation and presentation, general reporting guidance.

Analysis of the extant literature reveals that the beginning of $\langle\mathrm{IR}\rangle$ is anchored in 1999 with the release of the "Value Reporting Framework" by PWC and the release of the first integrated report in 2002 by Novozymes, a Danish enzyme company (De Villiers, Rinaldi and Unerman, 2014; Flower, 2015). These two events led to the opening up of debate and discussions on $\langle\mathrm{IR}\rangle$. Ultimately, development of $\langle\mathrm{IR}\rangle$ as concept took place with the establishment of the IIRC in August, 2010 (Flower, 2015; Adams, 2013). Dumay, Bernadi, Guthrie and Dermartini (2016) stretch the origins of <IR $>$ to as early as 1994 with the release of South Africa's first King Code of Corporate Governance (King I). They take the narrative through King II, King III and ultimately to 2010 when the IIRC was established. This paper somehow challenges this <IR> discourse. Rather it departs from this position regarding the birth of $\langle\mathrm{IR}\rangle$ by turning back the hands of time to $5000 \mathrm{BC}$ when financial accounting was first developed in Babylon. It is contended that $\langle\mathrm{IR}>$ was born out of the need to account properly to the ever changing needs of stakeholders and this partly contributed successive births and subsequent development of Financial Reporting, Balanced Scorecard (BSC), Triple Bottom Line (TBL), Sustainability Reporting (SR) and $\langle\mathrm{IR}\rangle$. In the following sections, the author attempts to draw a link on how accountability needs for the social and environmental realities contributed to the birth of financial reporting, BSC, TBL, SR, and <IR $>$.

\section{Financial reporting}

Evolution of financial reporting can be best analysed using the approach adopted by Cronjé (2007:27) where the analysis is divided into three distinct stages which are ancient times, middle times and modern.

\section{Ancient times: 5000 BC-500BC}

Financial reporting as it is known today has evolved over time. Archaeological research recognises the presence of some form of primitive recordkeeping from about $5000 \mathrm{BC}$ (Edwards, 2014). Mattessich (1987) and Belkaoui (1992) however, place 3000 BC as the time when the first tablets of records were prepared. Recordkeeping emerged almost simultaneously with first civilisations of man in Mesopotamia, Babylon and Egypt and these were the first to produce the first organised governments in the world (Belkaoui, 1992). Records were in the form of symbols indicating goods, quantities and other business data. Recordkeeping evolved from pictures to symbols to letters and finally to writing. The symbols were usually animals or birds. The number of times an animal was repeated indicated the quantity, or having the symbol of a bird with missing feet or an extended neck indicated some numerical significance (Edwards, 2014, Most, 1982). Furthermore, scribes primarily recorded business transactions and land sales which were in the form of inventories, list of commodities used for payments, contracts of sale or loan and rarely, simple journal entries (Most, 1982). Below is a line graph which shows the development financial accounting from about $5000 \mathrm{BC}$ to $2005 \mathrm{AD}$, when the International Financial Reporting Standards (IFRS) were launched.

The Code of Hammurabi (named after the King of the first dynasty of Babylonia from 22852242 BC) is considered to be one of the first attempts to standardise the financial reporting process (Brown, 1968; Cronjé, 2007). The code required an agent selling goods for a merchant to surrender to the principal a sealed memorandum quoting the prices (Edwards, 2014). A rather similar type of accounting operated in Egypt during the time of Pharaohs as evidenced by the surviving example of Papyrus dated $2390 \mathrm{BC}$ which is made from reeds 
more common in the Nile Delta (Edwards, 2014). It was mainly the duty of scribes to prepare records of receipts and disbursements of mainly corn, silver and other commodities.

It is believed that in the ancient civilisations particularly in Babylon, early record keeping mainly developed in order to meet government and business needs. While this was so for Babylon, reporting was mainly to evaluate the success of the government and its personnel in ancient China (Cronjé, 2007:28). Still in the Chinese scenario, each government department was compelled to report on what it had done through an annual report which would then be audited by the "control-general". Record keeping further improved with the widespread use of papyrus rolls (Edwards, 2014). Government accounting was also practiced in the Roman Empire and is estimated to have been in place from about $200 \mathrm{BC}$. The system was highly developed reporting on revenue collected, expenditure incurred and any other financial transaction. It is interesting to note that as early as $84 \mathrm{BC}$, the system was already abiding by the principle of separation of duties where scribes prepared the accounts while proquaestors supervised and audited the accounts (Edwards, 2014).

The striking feature of this era (ancient times) is that the double-entry principle as it is known today, emerged as early as $3200 \mathrm{BC}$ though it only became popular after Luca Pacioli in 1494(Mattessich, 1987). Arranging tokens in the clay envelopes represented the quantities of various assets which in a sense is a debit entry. Mattessich (1987) further argues that there was need to fulfil two requirements which are revealing from outside the contents of the envelope and revealing at a glance the entire equity of the envelope. This would be done by impressing hardened tokens into the surface of the softer clay envelope. This second exercise is deemed to be mirror impressions of the earlier recording. So in a sense it represents the credit entries, hence birth of the duality principle as it is understood today.

\section{The Middle Ages: 400 BC- 1700AD}

Two major developments to financial reporting are found in this period. The first one is development of "Capitulare de Villis" which emerged in the ninth century (Cronjé, 2007) in the Roman Empire during the reign of Charlemagne (768-814 AD) who is also known as Charles the Great or Charles I or King of the Franks. This document was developed to lay out rules and regulations on how to administer animals, land, justice, revenue collection and distribution, and the overall administration of the emperor's properties and assets. One may contend that this document was the seed of IFRS which was planted by Charles the Great and which only sprouted in 2005 with the release of International Accounting Standards (IASs). In other words, characteristics of an observable accounting system emerged with the release of the "Capitulare de Villis".

The second major event in the development of financial reporting is the publication in 1494 of the book entitled Summa de Arithmetica, Geometria Proportioni et Proportionalita which is translated to Summary of Arithmetic, Geometry, Proportions and Proportionality. Luca Pacioli, a Franciscan friar is the author of this book. Pacioli is generally credited as the father of double entry accounting not because he created it, but because he was the first one to document this practice which has been in use in Venice for over 200 years (Cronjé, 2007). In that book, Pacioli explains the "Method of Venice" also known as "the Italian method" where debit (adebeo) and credit (credito) were identified as the elements required to secure a double entry. Pacioli further suggested in the book not to only record the name of buyer or seller or the description of a good with its weight, size or measurement but rather include terms of payment (Belkaoui, 1992). Finally, the book has advice of computing periodic profit and closing of books at the end of the year. Ultimately the book was translated into various 
languages and this greatly contributed towards the spread and popularity of the Method of Venice. In summary, one may content that Summa de Arithmetica, Geometria Proportioni et Proportionalita stands out distinctively by bringing about a new face to financial reporting by systematically recording formally the accounting practice that prevailed at the time.

\section{Modern Times: 1700 AD-present financial reporting}

The Industrial Revolution in Europe and America in 1700s brought about fundamental changes in the financial reporting landscape (Cronjé, 2007). This period can be described as one in which predominantly agrarian rural societies became increasingly urban and industrial and this was marked by a transition from domestic production to factory production (Most, 1982). This transition contributed towards growth in size of the company and the respective capital requirements. The need to raise these capital requirements then led to a request for meaningful accounts by promoters and shareholders. The preparation of accounts was governed by the English Companies Act which was adopted in 1862 (Cronjé, 2007). As the accounts became more complex, there was a call especially in Great Britain to have these accounts audited and this created a need for public accountants (Most, 1982). Further developments in financial reporting were also realised in South Africa with the adoption in 1909 of the South African Companies Act which was modelled along the English Companies Act. The South African Companies Act was amended twice, in 1926 and 1973 so as to cater for the continuous developments in financial reporting. Another striking feature of this era is the emergence of the generally accepted accounting principles (GAAP) which mainly guided the mandatory disclosures. GAAP emerged in the 1970s and many developed countries crafted their own sets of GAAP to guide recognition, measurement and disclosure of transactions (Cronjé, 2007).

Developing one global set of accounting standards as compared to each country using its own GAAP was essential so as bring a number of benefits which accrue from following universally accepted IFRS. Some of the benefits as argued by El-Gazzar, Finn and Jacob (1999) include a reduction in costs associated with financial analysis and disclosure, thereby resulting in more efficient markets, which in turn would enhance cross boarder financing and trade. Non-compliance with IFRS, leads to the incomparability of financial statements produced in different geographical locations, which leads to the inefficient allocation of capital, reduced cross boarder investment, non-credibility of local markets to foreign investors and difficulty in consolidation of financial investments. The first set of IFRS was adopted in January 2005 by the European Union, Hong Kong, Australia, New Zealand and South Africa, and other countries followed thereafter. Currently about 114 jurisdictions require the use of IFRS by all or most public companies (IASB, 2015). It is important to mention also that at this stage, the United States of America (US) through the Financial Accounting Standards Board (FASB) has not yet adopted the IFRS but serious discussions are in place towards converging the US GAAP and the IFRS. Despite such a long developmental and survival history, financial reporting has been placed under the microscope and some of the criticism are discussed below.

\section{Criticism of Financial Reporting}

There is a school of thought which reiterates the view that other reporting systems like the balanced scorecard, triple bottom line and sustainability developed mainly due to the failure of financial reporting to capture the social and environmental externalities caused by the reporting entity (Deegan and Unerman, 2011). As such, in this section an attempt is made to 
elaborate some of these limitations. The first criticism is that financial reporting is premised on several assumptions and principles which hinder entities from incorporating social and environmental aspects of their operations. In fact the financial accounting conventions make it unrealistic to include the social and environmental reports in the main financial accounting report (Deegan, 2013). The argument is extended to the International Accounting Standards Board Conceptual Framework for Financial Reporting (2010) which is deemed to be actually an obstacle that blocks financial accountants from debating meaningfully about holistic reporting because it clearly states that the purpose of financial reporting is to provide financial information to current and potential investors (Deegan, 2013). A similar view is echoed by Gray (2013) when he contends that financial accounting will only cater for an environmental occurrence only to the extent that it affects accounting numbers. In other words, if there are social and environmental aspects that are affected by the entity, then they will be ignored only and until they start to affect the accounting numbers.

The second criticism levelled against financial reporting is the backbone of accounting in the form of the double entry principle. It is argued that since its documentation in 1494 through the Summa de Arithmetica, Geometrica, Proportioni et Proportionalita (a book written by the Franciscan Monk, Luca Pacioli); double entry was devised for relatively smaller organisations without complex ownership structures. As a result, the principle sometimes fails to capture one-sided notional costs which arise from externalities where costs are allocated to external parties but where there is no direct outflow of resources from the entity (Deegan, 2013). In line with the double entry concept, the entity principle is also criticised. It reckons that an entity is distinct from its owners, other organisations and other stakeholders (Deegan and Unerman, 2011). As a result, any transaction that does not directly have influence on the entity will be completely ignored for accounting purposes. An example is given of externalities where damage is inflicted on the river system by an entity through some toxic waste. Then subjectively, a cost may be attached to that damage. The challenge still remains that the cost of damages will be a debit in the respective expense account but there will be no credit entry since the river is not owned by the entity because this whole notion is beyond the entity assumption (Deegan, 2013).

The third criticism raised against financial reporting is the concept of financial materiality. Financial accounting considers a transaction material if it can be measured reliably and highly probable that there will be some resource outflows and is also more importantly centred on the magnitude of the financial value of that transaction. Given the difficulty in quantifying social and environmental information, accountants tend to use their professional judgement not to record the social and environmental transactions basing on their immateriality (Deegan, 2013; Deegan and Unerman, 2011). Although companies are slowly starting to recognise social and environmental implications based on their potential to financial materiality, however a lot still needs to be done.

The fourth criticism pronounced against financial reporting is that elements (assets, liabilities, equity, income and expenses) of financial reporting are defined in a way that excludes any impact on resources that are shared and not controlled by the entity. These resources are for instance air, rivers, ocean, rivers (Deegan and Unerman, 2011). Therefore their use or abuse is not at all considered from a financial reporting perspective and hence no externalities would be recognised (Deegan, 2013). Continuing along the line of defining elements of financial accounting, there is yet another observation that financial reporting actually acts as bulwark that discourages entities from capturing social and environmental impact. Financial reporting rather punishes entities which attempt to do the right thing by reducing their profits through greater amounts of depreciation, losses on disposal of non-current assets, increased 
labour and machine hours and this is understood as a disincentive for investment in cleaner technologies (Deegan, 2013).

The fifth criticism for financial reporting is that practice of discounting liabilities to their present value especially those that remain unsettled for a period over 12 months. Gray et al. (1996) opine that this makes economic sense but rather not so much ecological sense because it downplays the importance of a future clean-up, thus literally transferring current environmental problems to future generations (Deegan, 2013). The last issue where financial reporting is placed under the microscope is the convention of verifiability. Verifiability is explained by the IASB Conceptual Framework as where preparers (or any other user) of financial information and independent observers reach a reasonable consensus that the record as presented is a true and fair view of what the record purports to represent. Given the nonverifiability nature of externalities, it leaves financial accounting with very little to offer in as far as recording social and environmental impact is concerned (Deegan, 2013). Though it is primarily an internal user reporting framework, BSC sprouted in an attempt to redress the above mentioned shortfalls.

\section{Balanced Scorecard}

KPMG through its research arm called the Nolan Norton Institute, in 1990 sponsored a oneyear study on multi-companies. The study was entitled "Measuring Performance in the Organisation of the Future". The research team comprised David Norton who was the CEO of the Nolan Norton Institute, Robert Kaplan an academic consultant and representatives from 12 companies (Kaplan and Norton 1996). The study was driven by the belief that performance measurement systems which rely on financial measures only were obsolete and were limiting opportunities to create economic value (Kaplan and Norton, 1996). The first performance measurement to be analysed by the participants was the one called the "Corporate Scorecard" which was initially used by Analog Devices. After adding some performance measures in the "Corporate Scorecard", the findings in the study were first published in the Harvard Business Review (January-February 1992) under the title "The Balanced Scorecard - measures that drive performance" (Kaplan and Norton, 1996). This publication marks birth of the Balanced Scorecard.

Kaplan and Norton (1996) define the Balanced Scorecards as an internal performance measurement framework that details financial and non-financial information for management and reporting purposes. Balanced Scorecard has four main perspectives, where each perspective posed a question and the answer to the question would become the goal that would be translated into a performance measure. The four perspectives and questions were; Financial - How do we look to our shareholders? Customer - How do customers see us? Internal business - What must we excel at? Innovation and learning perspectives - Can we continue to improve and create value?

\section{Criticism of the Balanced Scorecard}

While the BSC partially addresses some of the weaknesses of financial reporting, it is however criticised for the lack of social, environmental and sustainability measures, which are important for future performance (De Villiers, et al., 2014). This idea is further accentuated by other critics of the BSC who contend that the four perspectives do not represent the interests of all stakeholders (Nørreklit, 2000; Kenny, 2003). In fact some scholars assert that suppliers, competitors, governments, local communities and the environment receive little attention (Lord, Shanahan and Gage, 2005; Kenny, 2003; Nørreklit, 2000). Nørreklit (2003) takes the debate further by positing that BSC perspectives 
are broad and ambiguous and this leaves too wide a room for personal interpretation and this freedom and flexibility would double up as a source of mistakes and malfunction in the context of BSC implementation and continued use.

The BSC has also received some critique particularly on some of its assumptions. Nørreklit (2000) argues that the cause-and-effect assumption has questionable validity and this undermines the credibility of the performance measurement system. Furthermore, the concept of linking measures to strategy in cause-and-effect relationships was not so well understood particularly by early adopters (Malmi, 2001). Nørreklit (2000) further questions using the BSC as a strategic control model mainly because of its rigidity and static focus. It rather omits and ignores competitive threats, technological developments and strategic uncertainty. The recommendation by Kaplan and Norton (1996) of having between four to seven performance measures on each of the four BSC perspectives is considered too broad and may lead to information overload and impaired judgement (Hoque, 2003).

The last criticism levelled against BSC is that the language used is merely persuasive rhetoric as opposed to academic writing grounded in sound argumentation and based on logic and reason (Nørreklit, 2003). The language is rather in dramatic form in order to create enthusiasm and excitement among readers (Lord, et al. 2005). Use of emotive language, hyperbole, unsound analogy and other stylistic devices leads to the dismissal of the BSC as a common rhetoric found in management texts which can be equated to cheap propaganda (Nørreklit, 2003). In other words, the authors are questioning credibility of the BSC as a performance measure. The contention is that the BSC is not really a new innovation since there were other similar performance measures like the French Tableau de Bord. One may therefore infer that the BSC's popularity was not because of its credibility, but rather due to the emotive language employed in it. As a result, TBL developed so as to counter the deficiencies of BSC.

\section{Triple Bottom Line}

The second framework which also emerged to address the shortcomings of corporate financial reporting is the TBL. This is an external reporting framework that acknowledges the interaction of three key interest areas which are economic success, environmental quality and social equity. The framework was founded by John Elkington and it became popular in the 1990s (De Villiers, et al. 2014).

\section{Criticism of TBL}

TBL has been criticised mainly because companies have been having a tendency of referring to social and environmental disclosures as sustainability disclosures yet in fact it was merely a symbolic connection to the term sustainability without any sustainability disclosures in substance (Brown, Dillard and Marshall, 2009). TBL has also been criticised for being illstructured, a poorly defined measure of reality, does not focus on improving or clarifying key measures of corporate well-being and does not present interrelationships between the major three components which are considered to be essential for corporate health (Sridhar, 2012). All the criticisms point to the fact that TBL failed to offer an internationally recognised reporting system that would replace or complement financial reporting.

\section{Sustainability Reporting}

Sustainability reporting which is also identified in the literature as Corporate Responsibility Reporting (CRR) or Corporate Social Responsibility (CSR) emerged when some companies 
were reporting on the social and environmental disclosures but however, they were doing so voluntarily and in an unsystematic manner. Sustainability reporting which is the third reporting system was developed and popularised by the Global Reporting Initiative (GRI) which was founded in Boston in 1997. The GRI released its first sustainability guidelines in 2000 and had its latest guidelines (G4) in 2013 (Berndt, Bilolo and Muller, 2014). For companies to be seen to cater for all stakeholder interests there was a notable increase in the number of companies that adopted these guidelines. According to the KPMG International Survey of Corporate Responsibility Reporting (2013), 71\% of the surveyed 4,100 companies issued corporate responsibility reports as compared to $64 \%$ of the 3,400 companies surveyed in a similar survey in 2011. The survey also notes that over $90 \%$ of the world's largest 250 companies now issue a CRR, and over $80 \%$ use the G4 guidelines.

\section{Criticism of SR}

While sustainability reporting is credited for bringing the social and environmental aspects into the reporting framework, however several criticisms have been pronounced against it. Two separate reports, namely the financial report and the sustainability report are prepared under this system and these two reports are not connected or linked to each other. In other words they are rather standalone reports which are isolated from each other (Abeysekera, 2013). Other disadvantages presented against sustainability reporting are that it focuses only on the short term; disclosures are narrow; the reporting system is rules bound; the reports are long and complex; some of the sustainability reports are paper based; and it mainly focuses only on the past and on financial matters (Berndt, Bilolo and Muller, 2014).

Another criticism levelled against sustainability reporting is about the quality of reports which remains relatively low and there are concerns related to the culture of sustainability practices within organisations (Gray, 2001). In fact, sustainability has also been criticised as merely a public relations exercise which is not embedded in the organisational conventions, customs and laws (Gray, 2010). It can as well be argued that the absence of norms, regulation, standards, unreliable measurement, low mobilisation of practices, incompleteness and poor quality of the reports are some of the reasons why sustainability has failed to enter into the mainstream financial reporting (Strong, 2014). While there are several criticisms pronounced for sustainability reporting, there is need for caution considering that assessing sustainability is rather a challenging and highly political endeavour with which the mainstream accounting is ill-equipped to deal with particularly balancing the ideological conflicts between profit-maximisation and human well-being (Brown and Dillard, 2014).

Although sustainability reporting managed to bring about a broadened accountability in the form of annual reports and sustainability reports, it failed to make it into the mainstream financial reporting. It is because reporting initiatives lack coherence with the long-term objectives of the organisations, and usually presented as unconnected activities performed within organisations (Abeysekera, 2013). Resultantly, a paradigm shift in corporate reporting came about when a new reporting system was developed so as to address some of the shortfalls of sustainability reporting particularly regarding the concept of value-creation process, value-creation for the organization and for others, longer-term strategic planning and a focus on the 'six capitals' (Adams, 2013b). 


\section{Integrated Reporting}

$<\mathrm{IR}>$ as a reporting framework is therefore defined by the IIRF as "a process founded on integrated thinking that results in a periodic integrated report by an organization about value creation over time and related communications regarding aspects of value creation". Furthermore, it defines an integrated report as "a concise communication about how an organisation's strategy, governance, performance and prospects, in the context of its external environment, lead to the creation of value in the short, medium and long term".. The Guiding Principles and the Content Elements of the $<I R>$ framework will be briefly described below.

The $\langle$ IR $>$ framework identifies seven Guiding Principles which guide organisations in the preparation of IARs and they are listed as; Strategic focus and future and orientation, connectivity of information, stakeholder relationships, materiality, conciseness, reliability and completeness, consistency and comparability. It further identifies nine Content Elements which have to be contained in an IAR and they are listed as; Organisational overview and the external environment, governance, business model, risks and opportunities, strategy and resource allocation, performance, outlook, basis of preparation and presentation, general reporting guidance.

\section{Criticism of Integrated Reporting}

Integrated reporting has brought some benefits like better risk identification and mitigation, transforming decision-making processes in a way which aligns benefits to society, business and the environment. However some criticisms have been levelled against it. Milne and Gray (2013:20) concur when they argue that, $<\mathrm{IR}>$ "is exclusively investor focused and it has virtually nothing - and certainly nothing substantive - to say about either accountability or sustainability". The guiding document, the Framework does not provide that entities should report on the full impact of their activities on stakeholders, society and the environment. The second criticism is that the Framework leaves far too much discretion to the firm's management and this ultimately makes comparison rather difficult if not impossible (Flower, 2015). In other words, $<\mathrm{IR}>$ is principles-based and this leads to low comparability among Integrated Reports. The principles-based approach further prefers more responsibilities to the top management and there is a possibility to conceal opportunistic behaviours. Lastly, the assurance levels are very low due to the presence of non-financial information and this compromises the reliability and capability of entities to providing a true and fair view of their value creation story (Miller, 2010).

\section{Findings and Conclusions}

The study finds that the changing needs of stakeholders led to a change in accountability patterns, which partly contributed to the birth and development of Financial Reporting, Balanced Scorecard, Triple Bottom Line, Sustainability and Integrated Reporting, especially to cater for the Social and Environmental aspects. Furthermore, although Financial Reporting is subjected to some to critique in the literature, it remains a useful and value relevant corporate reporting system which is strengthened by audit assurance. The study further finds that origins of Integrated Reporting cannot be limited to 2002, as explained in the paper, but rather the seed germinated in 5000BC and grew through time to become Integrated Reporting. Lastly it was noted that while <IR $>$ has all the promises to become a global reporting system, it was found to possess some shortcomings which include being silent about sustainability, being principles-based which leads to low comparability levels. 


\section{References}

Abeysekera, I. 2013. A template for integrated reporting. Journal of Intellectual Capital, no. 14 (2), pp. 227-245.

Adams, C. A. (2013b). Resources for integrated report preparers and topics for researchers. Towards sustainable business. [online]

Available at: http://drcaroladams.net [Accessed 28.04.15].

Adams, C. A. (2015). The International Integrated Reporting Council: A call to action. Critical Perspectives on Accounting, no. 27, pp. 23-28.

Belkaoui, A. R. (1992). Accounting Theory. USA, Chicago: Thomson

Brown, R. (1968). History of accounting and accountants. New York: Augustus M. Kelley.

Cronjé, C. J. (2007). Corporate Annual Reports (CARS): Accounting Practices in Transition. Doctoral Thesis, University of Pretoria, Pretoria, Gauteng Province, South Africa.

De Villiers, C., Rinaldi, L., Unerman, J. (2014). Integrated Reporting: Insights, gaps and agenda for future research. Accounting, Auditing \& Accountability Journal no. 27 (7), pp. $1042-1067$.

Deegan, C. (2013). The accountant will have a role in saving the planet...really? A reflection on 'green accounting and green eyeshades twenty years later. Critical Perspectives on Accounting, no. 24 (2013), pp. 448-458.

Deegan, C., Unerman, J. 2011. Financial Accounting Theory. United Kingdom: McGraw-Hill Education.

Dumay, J., Bernardi, C., Guthrie. J., and Dermartini. 2016. Integrated Reporting: A structured literature review. Accounting Forum. [online] 40 (3), pp. 166-185.

Available at: http://dx.doi.org/10.1016/j.accfor.2016.06.001

Edwards, J. R. (2014). A history of financial accounting. United States: Routledge.

El-Gazzar, M. S., Finn, M.P. and Jacob, R. (1999). An empirical investigation of multinationals' firms compliance with international accounting standards. The Journal of International Accounting, 34 (2), pp. 239-248.

Flower, J. 2015. The international Integrated Reporting Council: A story of failure. Critical Perspectives on Accounting, 27 (2015), pp. 1-17.

Gray, R. (2013). Back to basics: What do we mean by environmental (and social) accounting and what is it for? A reaction to Thornton. Critical Perspectives on Accounting, 24 (2013), pp. 459-468.

Gray, R., Owen, D., Adams, C. (1996). Accounting and Accountability: Changes and Challenges in Corporate Social and Environmental Reporting. London: Prentice Hall.

International Integrated Reporting Council (2013a). The International Integrated Reporting Framework. [online]

Available at: http://integratedreporting.org/wp-content/uploads/2013/12/13-12-08-THEINTERNATIONAL-IR-FRAMEWORK-2-1.pdf [Accessed 28 Sep. 2016].

Kaplan, R. S., Norton, D. P. (1996). The Balanced Scorecard. Boston, MA: Harvard Business School Press. 
Mattessich, R. (1987). Prehistoric accounting and the problem of representation: on recent archaeological evidence of the Middle-East. The Academy of Accounting Historians, 14 (2), pp. 71-91.

Miller, P. B. (2010). The effects of reporting complexity on small and large investor trading. Accounting Review, 85 (6), pp. 2107-2143.

Most, K. S. (1982). Accounting theory. Columbus, Ohio: Grid.

Nørreklit, H. (2000). The balance on the balanced scorecard - a critical analysis of some of its assumptions. Management Accounting Research, no. 11, pp. 65-88.

Nørreklit, H. (2003). The BSC: What is the score? A rhetorical Analysis of the BSC. Accounting, Organizations \& Society no. 28, pp. 591-619.

Simnett, R. and Huggins, A. L. (2015. Integrated reporting and assurance: where can research add value? Sustainability Accounting, Management and Policy Journal, no. 6 (1), pp. 29-53.

Sridhar, K. (2012). Is the Triple Bottom Line reporting framework flawed or it can be developed to a higher state? Doctoral Thesis, Macquarie University, Sydney, Australia.

Strong, P. T. (2014). Integrated reporting in Australia: A study of key interests and effects. Doctoral Thesis, University of New South Wales, Kensington, Australia. 